\title{
Religiosity as a Predictor of Consumer Ethical Behaviour: Some Evidence From Young Consumers From Malaysia
}

\author{
Zulkufly Ramly \\ University of Malaya, Malaysia \\ Lau Teck Chai and Choe Kum Lung \\ University Tunku Abdul Rahman, Malaysia
}

\begin{abstract}
Young consumers group has been a growing population of consumers in Malaysia. The group is increasingly cosmopolitan in its outlook and preferences, and highly exposed to various media and advertising tactics. As Malaysia is rapidly moving towards industrialised and modern economy, the changing socio-economic factors, growing affluence and declining moral and religious standards, especially in urban areas can play an important role in shaping the ethical orientation of young consumers. This research examined the role of religiosity in determining the ethical attitudes of young consumer groups in Malaysia. Undergraduate students represent the new generation of young consumers group. Hence, two hundred and seventy eight undergraduate business and accounting students in public and private universities in Kuala Lumpur, Malaysia were surveyed for this purpose. This research found limited evidence to support the hypothesis that religiosity was a positive determinant of young consumers' ethical beliefs in Malaysia. Further, the results also revealed that male young consumers were more willing to benefit from illegal activities as well as to passively benefit at the expense of others than did the female students.
\end{abstract}

\section{Keywords}

Gender, religiosity, ethical attitudes and values, and young consumers

\section{Introduction}

Corporations have various stakeholder groups whose influence and support are crucial in ensuring the enduring survival of the business. Consumers have long been recognised as one of the most influential stakeholder groups that could affect the well-being of a corporation. Consumers can be categorised into various segments. They can be grouped according to their age, income level, occupation hobbies or interest. For example, Lewis and Bingham (1991) classified young consumers as youths between the age of 15 and 24 years old. University

Copyright (C) 2008 Victoria University. This document has been published as part of the Journal of Business Systems, Governance and Ethics in both online and print formats. Educational and non-profit institutions are granted a nonexclusive licence to utilise this document in whole or in part for personal or classroom use without fee, provided that correct attribution and citation are made and this copyright statement is reproduced. Any other usage is prohibited without the express permission of the students fall within this market segment and they represent a new generation of consumers capable of making a strong and potential impact on business practices. In business ethics research, students are probably the most frequently researched stakeholder group and there has been 
numerous studies utilising them as survey or study participants.

In Malaysia, students who represent the young consumers group have been a growing population. They are not only increasingly cosmopolitan in their outlook and preferences but also highly exposed to various media and advertising tactics. As Malaysia is moving towards industrialised and modern economy, the growing affluence and potential declining moral and religious standards especially in urban areas can play an important role in shaping the ethical orientation of the young consumers. Moreover, given the fact that today's university students may be the future business leaders and entrepreneurs in our society this research set out to test whether religious commitment influences their ethical attitudes. One issue that would be explored is the ethical stance of the new generation of consumers on their acceptance of ethical and potentially unethical situations. Are they more accepting of unethical behaviours or are they less tolerant of unethical behaviours? To what extent is their personal religiosity influencing their ethical attitudes and beliefs? Ethical or unethical consumer practices can be explained as the rightness or the wrongness of certain actions on the part of the buyer or potential buyer in consumer situations (Dodge, Edwards, and Fullerton, 1996). Examples of unethical consumer practices include drinking a can of coke in a supermarket without paying for it, returning a "money back guaranteed" product after trying it and not liking it and getting too much change and not saying anything.

This proposed research is essentially exploratory in nature and has three objectives. The first objective is to investigate the influence of religiosity on ethical attitudes of university students in Malaysia. The second objective is to compare the extent to which religiosity influences the ethical attitudes of public and private university students in Malaysia. Finally, the third objective is to investigate the effect of gender on consumer ethical beliefs.

This study will contribute towards research in ethical judgments and consumer practices in the Malaysian perspective. Specifically, the study will provide some insights on the influence of religious commitment on the attitudes towards various unethical consumer practices among young consumers in Malaysia. The insightful findings might help formulation of appropriate policy or best practices to promote ethical consumer practices among Malaysian consumers. In addition, knowing the ethical orientation of potential future business leaders might provide academicians and policy makers the means to shape appropriate ethical attitudes early, while they are still studying for their tertiary education. The paper will begin by providing a theoretical background of the relevant literature. Thereafter the methodology and the results from the quantitative study will be presented. The paper will conclude with a discussion of the findings and limitations for future improvement.

\section{Literature Review}

\section{Demographic composition of Malaysia}

As the present study involved undergraduate students in Malaysian universities, it was necessary to provide a snapshot of the demographic composition of the Malaysian population especially in terms of race and religion. Malaysia is a multiracial country with Malays and other Bumiputra make up $65 \%$ of the population, Chinese 27\%, and Indian 8\% (Department of Statistics, 2000). Malays in Malaysia are by definition Muslims, according to Article 160 of Federal Constitution (The Commissioner of Law, 2006). On the other hand, $76 \%$ of Chinese regard themselves as Buddhists while $85 \%$ of Indians believe in Hinduism (Department of Statistics, 2000). In addition, an affirmative action in public university enrolment had been practiced since the 1980s in order to improve the number of Malays and Bumiputra students (Joseph, 2008). As a result, most Chinese and Indians choose to further their studies in the private universities. Malay students made up the largest fraction of student population in public universities whilst many Chinese students tended to enrol in private universities. 


\section{Consumer ethics}

Consumer ethics refers to the moral values and beliefs that individuals or groups observe when they buy, consume and dispose of products and services (Muncy and Vitell, 1992). Ethical issues involving consumers are equally as important as other marketing and advertising practices. Hence, it is pertinent to study consumer behaviour in ethics research so as to gain a broader understanding of ethical issues in the marketplace (Vitell, 2005). However, in the past there was a noticeable lack of attention given to this area of ethics. In the early 1990s, empirical research on consumer ethics was limited and focused mainly on the buyer side of the buyer-seller dyad. Hence, in a study on consumer ethics, Muncy and Vittell (1992) established a scale to measure consumer ethical attitudes pertaining to different types of ethical situations. They found that consumers reacted differently to different kinds of ethical issues/situations. Overall, consumers perceived that actively benefiting from illegal activities was more unethical compared to passively benefiting.

The Muncy-Vitell consumer ethics scale consists of four distinct dimensions: (1) actively benefiting from illegal activities, (2) passively benefiting, (3) actively benefiting from deceptive but legal practices and (4) no harm activities. The first dimension signifies the behaviour in which the consumers actively take advantage of a situation at the expense of the seller. For example, a customer gives misleading price information to cashier when the price tag has been peeled off. The second dimension consists of a situation where consumers passively benefiting themselves due to the seller's mistake. An example of this situation is when a customer gets too much change and does not inform the cashier. The third dimension represents actions in which consumers are actively involved in unethical but not necessarily illegal practices. For example, a customer keeps quiet when a waitress at the fast food restaurant serves him first instead of the other customer waiting in front of him. The final dimension refers to the behaviour that is not seen as harmful to others. An example of this situation is the act of spending an hour trying on different shoes and not purchasing any.

The Muncy-Vitell consumer ethics scale has been widely used in subsequent research including in the cross-cultural context (e.g. Polonsky, Brito and Higgs-Kleyn, 2001; Al-Khatib, Vitell and Rawwas, 1997; Rawwas, Strutton and Johnson, 1996; Rawwas, Vittell and Al-Khatib, 1994). In 2005, the consumer ethics scale was modified and a new dimension that represents consumers' desire to recycle products and "do the right thing" was added (Vitell and Muncy, 2005). However the present study did not utilise this modified version.

\section{Religion and religiosity}

Johnstone (1975) defined religion as a system of beliefs and practices by which a group of people interpret and respond to what they feel is mystical and revered. Furthermore, religion is a social institution that shapes and controls the beliefs and behaviour of its followers. Religion affects individual behaviour through two sources. First, religion stipulates rules and obligations as well as sanctions that directly control and influence individual's behaviour (Harrell, 1986). One example might be the prohibition of gambling and consumption of liquor for Muslims. Second, as an influential social institution, religion has an indirect role in shaping culture, norms, attitudes and values in society (Al Habshi and Syed-Agil, 1994).

Religiosity or religious commitment is "the extent to which an individual is committed to the religion he or she professes and its teachings, such as the individual attitudes and behaviours reflect this commitment" (Johnson, Jang, Larson and Li, 2001: p. 25). The influence of religion on individual's ethical orientation stems from its highly personal nature. Hence, the extent to which religion affects one's beliefs and behaviour depends on the individual's level of religiosity and the importance one places on the religion itself (Sood and Nasu, 1995). For example, Magill (1992) reported that personal religiosity could be used to rationalise the ethical nature of behaviour. In addition, Giorgi and Marsh (1990) indicated that religion and the level of religiosity positively influenced an individual's ethical stance. Huffman (1988) argued that religiosity was one of the strongest determinants of values. Hence, 
religious persons exhibit value systems that differ from those less religious and the non-religious (Mokhlis, 2006).

Previous empirical studies found mixed evidence on the positive influence of religiosity on an individual's perception of an ethical situation. For example, Clark and Dawson (1996) found that religious people tended to be more tolerant of ethically questionable corporate behaviour. Similarly, Agle and Van Buren (1999) failed to find support on the relationship between religious upbringing and corporate social responsibility. However, a few other empirical studies found a negative relationship between religiosity and one's ethical orientation. Hunt and Vitell (1993) and Phau and Kea (2007) found that religiousness could affect an individual's perception of an ethical situation and other components of ethical decisions. Both studies discovered that people who practiced their religion tended to consider themselves more ethically minded than those who did not. Hence the strength of religiousness might lead to differences in one's decision making process. Furthermore, Weaver and Agle (2002) reported that individuals formed a religious self-identity based on the teachings of religion, which in turn shaped their behaviour and attitudes. In a recent study on ethical attitudes of college students in the United States, Albaum and Peterson (2006) reported that students who claimed to be highly religious tended to behave more ethically than those who were less religious.

Tsalikis and Fritzsche (1989) and Stassens (1977) suggested the importance of a theological or religious commitment in developing a framework for business ethics. In addition, other studies had documented strong theoretical support on the existence of relationship between religiosity and attitudes towards business ethics (see Mokhlis, 2006; Vitell, Paolillo, and Singh, 2005; Kennedy and Lawton, 1998; Tepstra, Rozell, and Robinson, 1993). All of these studies reported that the level of religiosity was generally associated with higher ethical attitudes. Most importantly, it is inferred that religiosity influences an individual's behaviour and attitude in a positive way.

Caird (1987) proposed that religiosity could be measured based on three dimensions: cognitive (focuses on religious attitudes or beliefs), behavioural (measures that seek to evaluate church attendance or private prayer), and experiential (query that relates to mystical experiences). Worthington, Wade, Hight, McCullough, Berry, Ripley, Berry, Schmitt, Bursley and O'Connor (2003) developed the Religious Commitment Inventory Scale (RCI-10) to measure religiosity. The RCI-10 consists of 4 dimensions of intrapersonal religiosity (cognitive) and 6 dimensions of interpersonal religiosity (behavioural) to a religious value system respectively. The intrapersonal religiosity dimension focuses on religious attitudes or beliefs and the interpersonal religiosity measures seek to evaluate mosque/temple/church attendance or private prayer. An example of intrapersonal religiosity statement would be "religion is especially important to me because it answers many questions about the meaning of life." Meanwhile, an example of interpersonal religiosity statement might be "I enjoy spending time with others of my religious affiliation."

\section{Religiosity and consumer ethics}

In the specific context of consumer ethics, a review of past literature revealed that there was a lack of published research until recently, specifically linking religiosity with consumer ethical beliefs. Some prior studies in religiosity and consumer ethics classified religiosity into two categories: (1) extrinsic and (2) intrinsic. The "extrinsically motivated person uses his religion whereas the intrinsically motivated lives his religion" (Allport and Ross, 1967: p.434). Donahue (1985) argued that intrinsic religiosity correlated more highly than extrinsic religiosity with religious commitment. Hence, intrinsic religiosity tended to have positive relationship with ethical beliefs. Researchers have employed both types of religiosity in prior studies.

Vitell and Paolillo (2003) found that religiosity was an indirect determinant of consumer ethical beliefs. They concluded that further empirical investigation especially in different settings was necessary to confirm the relationship between religiosity and consumer ethical behaviour. Vitell, Paolillo, and Singh (2005) used a sample of undergraduate students and investigated the role that intrinsic and extrinsic religiosity played in determining consumer attitudes in various situations regarding questionable 
consumer practices. They discovered that intrinsic religiousness was the only significant determinant of consumer ethical beliefs. This was consistent with the findings of Vitell and Paolillo (2003).

Vitell, Paolillo, and Singh (2006) examined the intrinsic religiosity only. Consistent with the findings of their previous research, they found that intrinsic religiosity was a significant determinant of consumer ethical beliefs. In a related study, Vitell, Singh and Paolillo (2006) used a non-student population to investigate the role of religiosity, money ethics and attitudes toward business in determining consumer ethical beliefs. They utilised Muncy-Vitell consumer ethics scale and discovered that intrinsic religiosity was a significant predictor for three dimensions of the consumer ethical beliefs. Meanwhile, extrinsic religiosity significantly explained only one consumer ethics dimension. Hence, this study provided mixed evidence on the role of religiosity in affecting consumer ethical beliefs.

\section{Gender effects}

In addition to an individual's religiosity, gender has also been found to be a significant predictor of ethical attitudes and perceptions. Ford and Richardson (1994) conducted a review of fourteen articles and reported that seven studies found that women tend to behave more ethically than men. In a recent review of literature, it was revealed that most prior studies reported a significant gender effect in the ethical attitudes of students (Albaum and Peterson, 2006). For example, Borkowski and Ugras (1998) reported that female students displayed stronger ethical attitudes than did the males. Rawwas, Swaidan and Al-Khatib (2006) found that gender was a significant predictor in explaining the differences in the relationship between individual student's religiosity and unethical behaviour. This study also reported that male students tended to behave less ethically than their female counterparts. In the context of consumer ethics, Rawwas (1996) reported that female consumers tended to view unquestionable consumer practices more negatively than did the males.

The significant differences in ethical attitudes in terms of gender may be due to the fact that men and women generally apply different decision rules when making ethical judgments (Callahan, 1990; Keller, 1988) and women tended to use a variety of decision rules compared to men (Galbraith and Stephenson, 1993). Based on the findings of the study women used utilitarian rule, that is, a decision rule based on outcomes or consequences. In contrast, men tended to use egoist rule, that is, decision rule based on maximising own self-interest. In addition, Arlow (1991) demonstrated that women place less emphasis on expediency, selfish interests, and "commonly accepted practice" than men when evaluating ethical issues. In terms of moral orientation, women are more 'cause' orientated whilst men are more 'justice' oriented (Gilligan, 1977). Based on previous empirical research on university students, there was conclusive evidence with respect to the influence of gender on the attitudes toward unethical behaviour.

\section{Hypotheses}

Based on the theoretical and empirical literature concerning the role of religiosity in determining the consumer ethical beliefs, the following hypotheses were proposed:

\section{H1: Interpersonal religiosity (religiosity) is a positive determinant of all dimensions of consumer ethical beliefs for public university students.}

H1a: Interpersonal religiosity (religiosity) is a positive determinant of consumer ethical beliefs regarding the active/illegal dimension for public university students.

$\mathrm{H} 1 \mathrm{~b}$ : Interpersonal religiosity (religiosity) is a positive determinant of consumer ethical beliefs regarding the passive dimension for public university students.

H1c: Interpersonal religiosity (religiosity) is a positive determinant of consumer ethical beliefs regarding the active/legal dimension for public university students.

H1d: Interpersonal religiosity (religiosity) is a positive determinant of consumer ethical beliefs regarding the no harm/no foul dimension for public university students. 
H2: Interpersonal religiosity (religiosity) is a positive determinant of all dimensions of consumer ethical beliefs for private university students.

H2a: Interpersonal religiosity (religiosity) is a positive determinant of consumer ethical beliefs regarding the active/illegal dimension for private university students.

$\mathrm{H} 2 \mathrm{~b}$ : Interpersonal religiosity (religiosity) is a positive determinant of consumer ethical beliefs regarding the passive dimension for private university students.

$\mathrm{H} 2 \mathrm{c}$ : Interpersonal religiosity (religiosity) is a positive determinant of consumer ethical beliefs regarding the active/legal dimension for private university students.

$\mathrm{H} 2 \mathrm{~d}$ : Interpersonal religiosity (religiosity) is a positive determinant of consumer ethical beliefs regarding the no harm/no foul dimension for private university students.

H3: Intrapersonal religiosity (religiosity) is a positive determinant of all dimensions of consumer ethical beliefs for public university students.

H3a: Intrapersonal religiosity (religiosity) is a positive determinant of consumer ethical beliefs regarding the active/illegal dimension for public university students.

$\mathrm{H} 3 \mathrm{~b}$ : Intrapersonal religiosity (religiosity) is a positive determinant of consumer ethical beliefs regarding the passive dimension for public university students.

H3c: Intrapersonal religiosity (religiosity) is a positive determinant of consumer ethical beliefs regarding the active/legal dimension for public university students.

H3d: Intrapersonal religiosity (religiosity) is a positive determinant of consumer ethical beliefs regarding the no harm/no foul dimension for public university students.

H4: Intrapersonal religiosity (religiosity) is a positive determinant of all dimensions of consumer ethical beliefs for private university students.

H4a: Intrapersonal religiosity (religiosity) is a positive determinant of consumer ethical beliefs regarding the active/illegal dimension for private university students.

$\mathrm{H} 4 \mathrm{~b}$ : Intrapersonal religiosity (religiosity) is a positive determinant of consumer ethical beliefs regarding the passive dimension for private university students.

$\mathrm{H} 4 \mathrm{c}$ : Intrapersonal religiosity (religiosity) is a positive determinant of consumer ethical beliefs regarding the active/legal dimension for private university students.

H4d: Intrapersonal religiosity (religiosity) is a positive determinant of consumer ethical beliefs regarding the no harm/no foul dimension for private university students.

H5: There is a significant difference between male and female students with respect to all the four dimensions of consumer ethical beliefs.

H5a: There is a significant difference between male and female students with respect to ethical beliefs regarding the active/illegal dimension

H5b: There is a significant difference between male and female students with respect to ethical beliefs regarding the passive dimension.

H5c: There is a significant difference between male and female students with respect to ethical beliefs regarding the active/legal dimension. 
H5d: There is a significant difference between male and female students with respect to ethical beliefs regarding the no harm/no foul dimension.

\section{Methodology}

\section{Research setting}

Undergraduate business and accounting students of two universities (one public and one private) in Kuala Lumpur, Malaysia, were selected as subjects for this empirical study. The public university, under current investigation, is located in the urban area of Kuala Lumpur and has an enrolment of about 25,750 students. The private university was established at the beginning of this century and is located in suburban Kuala Lumpur. It has a current enrolment of about 14,000 students.

Undergraduate students were chosen as respondents due to their ready accessibility and their demographic characteristics fit the profile of young consumers. Feber (1977) argued that using students sample was considered valid for exploratory studies especially considering that the subject content of the research was both relevant and understandable to the respondents. Ahmed, Chung and Eichenseher, 2003 regarded the use of undergraduate students to be relevant and beneficial because as an influential consumer group, they represent the future professional managers and business leaders with high purchasing power. Moreover, they are gaining higher education in an era of growing attention and awareness given to the ethicality of business practices.

\section{Sample}

Two-self administered questionnaires were distributed to two groups of students. The first group comprised 150 business and accounting students attending a public university in Malaysia. The second group composed of 150 students enrolled in a private university in Malaysia. The students completed the survey during class time and were assured anonymity and remuneration was not offered. Two faculty members were assigned to distribute the questionnaires at the respective universities. A total of 278 questionnaires (yielding a response rate of 92.6\%) were deemed usable for data analysis. The remaining questionnaires were discarded due to incomplete or unsatisfactory responses. Table 1 and 2 below summarise the profile of the sample based on the type of university.

Table 1: Public university: demographic characteristics of the respondents $(n=138)$

\begin{tabular}{lcllllll}
\hline \multicolumn{2}{c}{ Gender } & \multicolumn{2}{c}{ Race } & \multicolumn{2}{c}{ Religion } & \multicolumn{2}{c}{ Taken ethics subject } \\
\hline Male & $15.2 \%$ & Malay & $65 \%$ & Muslim & $65 \%$ & Yes & $22.4 \%$ \\
Female & $84.8 \%$ & Chinese & $34 \%$ & Buddhist & $29 \%$ & No & $77.6 \%$ \\
& & Indian & $1 \%$ & Taoist & $4 \%$ & & \\
& & & Hindu & $1 \%$ & & \\
& & & & Christian & $1 \%$ & & \\
\hline
\end{tabular}

Table 2: Private university: demographic characteristics of the respondents $(n=140)$

\begin{tabular}{|c|c|c|c|c|c|c|c|}
\hline \multicolumn{2}{|c|}{ Gender } & \multicolumn{2}{|c|}{ Race } & \multicolumn{2}{|c|}{ Religion } & \multicolumn{2}{|c|}{ Taken ethics subject } \\
\hline Male & $30 \%$ & Malay & $0.7 \%$ & Muslim & $0.7 \%$ & Yes & $46 \%$ \\
\hline Female & $70 \%$ & Chinese & $97.9 \%$ & Buddhist & $69.3 \%$ & No & $54 \%$ \\
\hline & & Indian & $1.4 \%$ & Taoist & $12.1 \%$ & & \\
\hline & & & & Hindu & $1.4 \%$ & & \\
\hline & & & & Christian & $7.9 \%$ & & \\
\hline & & & & Others & $8.6 \%$ & & \\
\hline
\end{tabular}




\section{Research instrument}

A survey instrument consisting of a series of brief ethical situations and religiousness characteristics were administered to undergraduate students enrolled in business and accounting programmes in two universities in Malaysia. Three major constructs were measured in this research: consumer ethical beliefs, religiosity and gender. The dependent construct in the analyses was consumers' ethical beliefs as measured by the Muncy and Vitell's (1992) consumer ethics scale. The Muncy-Vitell consumer ethics scale consists of four distinct dimensions: (1) actively benefiting from illegal activities (passive/illegal), (2) passively benefiting (passive), (3) actively benefiting from deceptive but legal practices (active/legal) and (4) no harm / no foul activities (no harm/no foul).

Consumer's ethical beliefs were measured with twenty consumer situations that have ethical implications. Certain items were modified or dropped after the initial pilot test to suit the Malaysian scenarios and also in view of the changing patterns of consumerism among Malaysian young consumers. Consistent with common practice, a 5-point Likert scale was used to measure the ethical beliefs of consumers. For examples, respondents were requested to rate each behaviour ranging from (1) strongly believe that it is wrong to (5) strongly believe it is not wrong on the downloading of $\mathrm{mp} 3$ songs from the Internet, taping a movie from the television and reporting a lost item as "stolen" to an insurance company in order to claim insurance money.

The independent construct in this study was religiosity of the respondents. The present study adopted the Religious Commitment Inventory Scale (RCI-10) developed by Worthington, et al. (2003) to measure religiosity. The RCI-10 consists of four cognitive and six behavioural commitment dimensions to a religious value system. The four cognitive dimensions were known as intrapersonal religiosity whilst the six behavioural commitment dimensions were known as interpersonal religiosity. The intrapersonal dimension of religiosity focuses on the individual's belief or personal religious experience whilst the interpersonal dimension focuses on the level of activity in organised religious activities.

The RCI-10 scale composed of ten 5-point Likert-type statements ranging from (1) "strongly believe that it is wrong" to (5) "strongly believe it is not wrong. In developing the RCI-10 scale, the data used was based on a student sample in the U.S. The students in the sample were from religions such as Christian, Buddhist, Muslim or Hindu. Hence, the RCI-10 scale was considered appropriate and valid for the present sample that consisted of young consumers who were Muslims, Buddhists, or Hindus.

The reliability coefficients of the ten dimensions on the religiosity scale and the four dimensions of the consumer ethics scale are indicated in Table 3 below. Schuessler (1971) stated that a scale is considered reliable if it has an alpha value greater than 0.60. Hair, Anderson, Tatham and Black (1998) added that reliability estimates between 0.600 and 0.700 represent the lower limit of acceptability in quantitative research studies. Therefore, the alpha value greater than 0.600 for reliability estimates was used due to the exploratory nature of this research.

Table 3: Reliability of dependent and independent variable measures

\begin{tabular}{lcc}
\hline Construct & No. of items & Cronbach alpha \\
\hline Dependent: & & \\
Active/illegal & 4 & 0.616 \\
Passive & 5 & 0.734 \\
Active/legal & 6 & 0.766 \\
No harm/no foul & 5 & 0.619 \\
Independent: & & \\
Intrapersonal religiosity & 6 & 0.846 \\
Interpersonal religiosity & 4 & 0.810 \\
\hline
\end{tabular}

\section{Empirical model}

This research employed two statistical techniques to test the hypotheses; namely a multiple regression analysis and a t-test. First, the influence of religiosity on consumer ethical beliefs was examined using a 
standard multiple regression analysis modelled after Vitell, Paolillo \& Singh (2005). The relationship between the dependent variables (the four consumer ethics dimensions) and the independent variables (the intrapersonal and interpersonal religiosity, and gender) was assumed to be linear as follows:

$$
Y_{i}=\alpha_{i}+\beta_{i j} X_{i j}+\varepsilon_{i j}
$$

where $Y_{i}$ represented a vector of the four consumer ethics dimensions. $X_{i j}$ represented a vector of the three independent variables for each of the four consumer ethics dimensions. $\varepsilon_{i j}$ represented the error term that was assumed to have a multivariate normal distribution. The parameters $\alpha_{i}$ and $\beta_{i j}$ were estimated from the data using enter ordinary least squares techniques. The potential existence of multicollinearity problem between the variables was diagnosed using a variance inflation factor (VIF) test. The results revealed that all the variables have VIF values ranging from 1.178 to 2.180. According to Hair et al. (1998) a VIF value of less than 10 is acceptable, thus all variables were retained and used in the multiple regression analyses. Second, a t-test was used to examine whether male and female students differed with respect to the four dimensions of consumer ethical beliefs.

\section{Results}

Multiple regression analyses were conducted separately for public and private universities students to test $\mathrm{H} 1, \mathrm{H} 2, \mathrm{H} 3$ and $\mathrm{H} 4$ with interpersonal and intrapersonal religiousness, and gender as the independent variables. The four dimensions of consumer ethical behaviour were utilised as dependent variables. Four separate multiple regression analyses were carried for each group of young consumers (see Tables 4 and Table 5 below).

\section{Public university students: hypotheses one and three}

As shown in Table 4 below, the multiple regression results of Model 1, Model 3 and Model 4 indicated that religiosity (both interpersonal and intrapersonal dimensions) was not a significant positive determinant of young consumers' ethical beliefs in the public university. Only Model 2 was statistically significant in which intrapersonal religiosity was the significant positive determinant of the young consumers' ethical beliefs regarding the passive dimension. The interpersonal and intrapersonal religiosity and gender collectively explained 7.4 percent of the variance in the dependent variable, which was the passive dimension of the consumers' ethical belief. Overall, the results supported H3b but it could not conclusively be concluded that religiosity was a strong positive determinant of the ethical beliefs of young consumers in the public university in the sample.

Table 4: Multiple regression analyses: the influence of religiosity on ethical beliefs of public university students $(n=138)$

Model Standardised beta $t$-value $\quad$ Significance

(1) Dependent variable: active/illegal dimension Intrapersonal religiosity $\quad-1.008$ Interpersonal religiosity $\quad 0.965$

Adjusted $\mathrm{R}^{2}=0.002$

$-1.008$

0.965

0.315

- 1.510

0.336

Significance $=0.373$

(2) Dependent variable: passive dimension Intrapersonal religiosity

Interpersonal religiosity

$-0.026$

Gender

$-0.134$

Adjusted $\mathrm{R}^{2}=0.074$

$\mathrm{F}$-value $=4.534$

(3) Dependent variable: active/legal dimension

Intrapersonal religiosity

$-0.168$

$-0.058$
$-1.856$

$-0.204$

0.050

- 1.581

0.839

Significance $=0.005$

$$
-1.308
$$

$-0.452$

0.193

0.652 
Gender

Adjusted $\mathrm{R}^{2}=0.039$

F-value $=2.806$

(4) Dependent variable: no harm / no foul dimension

Intrapersonal religiosity

Interpersonal religiosity

0.039

$-0.194$

Gender

Adjusted $\mathrm{R}^{2}=0.038$
$-0.192$

F-value $=2.736$
$-1.240$

0.263

Significance $=0.042$

0.296

0.768

$-1.495$

0.137

$-2.238$

0.027

Significance $=0.046$

\section{Private university students: hypotheses two and four}

As for the ethical beliefs of young consumers in the private university (see Table 5 below), only Model 2 was statistically significant. Interpersonal religiosity and gender were the significant positive determinants of the young consumers' ethical beliefs regarding the passive dimension in the sample. The interpersonal and intrapersonal religiosity and gender collectively, explained 7.8 percent of the variance in the dependent variable, which was the passive dimension of the consumers' ethical belief. Overall, the results partially supported $\mathrm{H} 2$, in particular $\mathrm{H} 2 \mathrm{~b}$ but it could not be conclusively concluded that religiosity was a strong positive determinant of the ethical beliefs of young consumers in the private university.

Table 5: Multiple regression analyses: the influence of religiosity on ethical beliefs of private university students $(n=140)$

\begin{tabular}{|c|c|c|c|c|}
\hline Model & & Standardised beta & $t$-value & Significar \\
\hline \multirow[t]{5}{*}{ (1) } & \multicolumn{4}{|c|}{ Dependent variable: active/illegal dimension } \\
\hline & Intrapersonal religiosity & -0.012 & -0.089 & 0.929 \\
\hline & Interpersonal religiosity & -0.054 & -0.400 & 0.690 \\
\hline & Gender & -0.201 & -2.391 & 0.018 \\
\hline & Adjusted $\mathrm{R}^{2}=0.023$ & $\mathrm{~F}$-value $=2.5067$ & Signific & $\mathrm{ce}=0.642$ \\
\hline
\end{tabular}

(2) Dependent variable: passive dimension

$\begin{array}{lclr}\text { Intrapersonal religiosity } & -0.063 & -0.473 & 0.300 \\ \text { Interpersonal religiosity } & -0.329 & -2.485 & 0.014 \\ \text { Gender } & -0.155 & -1.902 & 0.050 \\ \text { Adjusted } \mathrm{R}^{2}=0.078 & \text { F-value }=4.934 & \text { Significance }=0.003\end{array}$

(3) Dependent variable: active/legal dimension

$\begin{array}{llll}\text { Intrapersonal religiosity } & -0.184 & -1.331 & 0.185 \\ \text { Interpersonal religiosity } & -0.208 & -1.503 & 0.135 \\ \text { Gender } & -0.010 & -0.117 & 0.907 \\ \text { Adjusted } \mathrm{R}^{2}=-0.005 & \text { F-value }=0.775 & \text { Significance }=0.510\end{array}$

(4) Dependent variable: no harm / no foul dimension

\begin{tabular}{llll} 
Intrapersonal religiosity & -0.097 & 0.697 & 0.487 \\
Interpersonal religiosity & -0.123 & -0.884 & 0.378 \\
Gender & -0.008 & -0.089 & 0.929 \\
Adjusted $\mathrm{R}^{2}=-0.16$ & F-value $=0.262$ & \multicolumn{2}{c}{ Significance $=0.853$}
\end{tabular}

\section{Gender effects: hypothesis five}

The results of the t-test supported hypotheses H5a and H5b (see Table 6 below). Male students in the sample were likely to be more unethical than female students in two out of the four dimensions of consumer ethics. Specifically, male students have shown more willingness to benefit from illegal 
activities as well as to passively benefit at the expense of others than did the female students. However, it could not be conclusively concluded that gender significantly influences the attitudes toward unethical behaviour of young consumers in the sample.

In summary, the results did not conclusively support that (1) religiosity is a positive determinant of young consumers' ethical beliefs, and (2) gender has a significant influence on the ethical beliefs of the young consumers in the sample. However, some positive findings were recorded in this study. First, intrapersonal dimension of religiosity influenced the young consumers in the public university in terms of the passive dimension of consumers' ethical beliefs. Second, interpersonal dimension of religiosity was found to have influenced the young consumers in the private university in terms of the passive dimension of consumers' ethical beliefs. Third, male students tended to show a more liberal attitude toward illegal activities as well as to passively benefit at the expense of others than did the female students. Hence, this research found some evidence on the significant role of religiosity and gender in determining the ethical attitudes of young consumers in the sample.

Table 6: T-test results of consumer ethics by gender $(\mathrm{n}=\mathbf{2 7 8})$

\begin{tabular}{lccc}
\hline Construct & $\begin{array}{c}\text { Male } \\
(\text { Mean })\end{array}$ & $\begin{array}{c}\text { Female } \\
(\text { Mean) }\end{array}$ & Significance \\
\hline Active/illegal & 2.3452 & 2.0845 & $0.001^{*}$ \\
Passive & 2.8921 & 2.5700 & $0.003^{*}$ \\
Active/Legal & 2.4974 & 2.3558 & 0.170 \\
No harm/no foul & 3.2794 & 3.3103 & 0.769 \\
\hline
\end{tabular}

$* \mathrm{p}<0.05$

\section{Discussion}

It is acknowledged that students represent the new generation of young consumers with strong potential impact on business practices. Given the lack of empirical study in this area of research in the context of Malaysia, the present study attempted to explore the potential impact of religiosity on ethical beliefs of this important segment of consumers. Two hundred and seventy eight undergraduate business and accounting students of one public and one private university participated in the survey research. This study found a very weak support for the role of religiosity in determining the consumers' ethical beliefs.

When comparing the young consumers in the public university and those in the private university, the study found that only one dimension of religiosity influences the ethical beliefs. Intrapersonal religiosity positively influenced the ethical beliefs of the young consumers in the public university with respect to the passive dimension of consumer ethics scale. Intrapersonal religious orientation focuses on the individual's belief or personal religious experience. It is worth noting that public university students in the sample mainly consisted of Malays $(65 \%)$ who were also Muslims. Hence a possible explanation for this finding could be related to the nature of Islam as a monotheistic religion that stresses the existence of one god who unifying the universe. It also places emphasis on one's spiritual being. Muslim young consumers in the sample tended to attribute the intrapersonal aspect of their religious orientation in their attitude toward potentially unethical situations.

In contrast, interpersonal religiosity was found to be a positive determinant of the ethical beliefs of the young consumers in the private university with respect to the passive dimension of consumer ethics scale. Interpersonal religiosity focuses on the extent of one's involvement in organised religious activities or rituals. The private university students in the sample mainly consisted of Chinese (98\%) who were mostly Buddhists or Taoists. Buddhism is considered a non-theistic religion, whose fundamental core does not include the idea of worshipping a creator god. Moreover, the practice of Buddhism in Malaysia has been largely infused by the elements of Taoism, which mainly focuses more on the ritualistic or cultural aspect rather than the spiritualistic. Hence, this conjecture may help to explain the finding of this research in the context of young consumers in the private university. In particular, Buddhist young consumers in the sample tended to attribute the interpersonal aspect of their religious orientation in their attitude toward potentially unethical situations. 
It is also important to note that the highly disproportionate student numbers in terms of race and religion in the sample from the public and private universities is reflective of the demographic composition of Malaysia as well the affirmative action policy that has been practiced since the 1980s. Hence, most Chinese and Indians choose to further their studies in the private universities. Moreover, the private university in this study was set up by a major political party that represents the Chinese in Malaysia. As such, majority of its student population is Chinese.

In the context of the effects of gender on the ethical orientation of young consumers, it was found that female consumers were negatively associated with unethical behaviour with respect to the active/illegal and the passive dimensions of consumer ethical beliefs. This finding is consistent with the findings of Borkowski and Ugras, 1998; Albaum and Peterson, 2006 and Rawwas, Swaidan and Al-Khatib, 2006). A possible explanation for this finding could be related to the upbringing of the young consumers. In Asian society, parents nurtured girls to be considerate, humble and obliging. Meanwhile boys were raised up to be tough-minded, aggressive and competitive. In addition, consistent with being nurtured to be thoughtful and considerate, previous studies found that women tended to use variety of decision rules when making ethical judgments (Callahan, 1990; Keller, 1988).

\section{Conclusions}

This research investigated the role of religiosity in determining the ethical attitudes of young consumer groups in Malaysia. Undergraduate university students in Malaysia were surveyed because they represent the thriving young consumers group that are highly exposed to modern marketing tactics and affected by the general decline in religious and moral standards.

The results indicated that only one dimension of religiosity influenced the ethical beliefs. Intrapersonal religiosity positively influenced the ethical beliefs of the young consumers in the public university with respect to the passive dimension of consumer ethics scale. On the other hand, interpersonal religiosity was found to be a positive determinant of the ethical beliefs of the young consumers in the private university with respect to the passive dimension of consumer ethics scale. In addition, it was found that female consumers were negatively associated with unethical behaviour with respect to the active/illegal and the passive dimensions of consumer ethical beliefs.

The results should be interpreted with caution due to the fact that the samples mainly consisted of either largely Malay (as in the case of the public university) or predominantly Chinese (as in the case of the private university). The findings of the identified weak relationships in this study should be taken as preliminary evidence that warrant further investigation across different samples so as to validate or verify the existing linkages. Future research should endeavour to include a representative sample of the Malaysian university students. Probably, future research should include other private and public universities in Malaysia. Only a small percentage of the variance was explained for the significant consumer ethics dimension. As such, the study has encountered an omitted variables problem in which other variables may account for the rest of the variance. Future research should include other variables such as the role of money, moral philosophies, race, and attitude toward business, exposure to ethics and religious-related courses and business versus non-business students.

\section{References}

Agle, B. R. \& Van Buren, H. J. (1999), God and mammon: the modern relationship. Business Ethics Quarterly, 9(4), pp. 563-582.

Ahmed, M., Chung, K. \& Eichenseher, J. (2003), "Business Students' Perception of Ethics and Moral Judgment: A Cross-cultural Study." Journal of Business Ethics, 43, pp. 89-110.

Al Habshi S. O. \& Syed-Agil, S. O. (1994), The role and influence of religion in society. Kuala Lumpur: Institute of Islamic Understanding Malaysia.

Al-Khatib, J., Vitell, S. J. \& Rawwas, M. Y. A. (1997), Consumer ethics: A cross-cultural investigation. European Journal of Marketing, 31, pp. 750-767. 
Albaum, G. \& Peterson, R. A. (2006), Ethical attitudes of future business leaders: Do they vary by gender and religiosity? Business and Society, 45(3), pp. 300-321.

Allport, G. W. \& Ross, J. M. (1967), Personal religious orientation and prejudice. Journal of Personality and Social Psychology, 5, pp. 432-443.

Arlow, P. (1991), Personal characteristics in college students' evaluations of business ethics and corporate social responsibility. Journal of Business Ethics, 10, pp. 63-69.

Borkowski, S. C. \& Ugras, Y. J. (1998), Business, students and ethics: A meta-analysis. Journal of Business Ethics, 17(8), pp. 117-127.

Caird, D. (1987), Religiosity and personality: Are Mystic Introverted, Neurotic, or Psychotic? British Journal of Social Psychology, 26, pp. 345-346.

Callahan, S. (1990), Is gender germane? Health Progress, pp. 21-24.

Clark, J. W. \& Dawson, L. E. (1996), Personal religiousness and ethical judgments: an empirical analysis. Journal of Business Ethics, 15, 359-372.

Department of Statistics (2000), The population and housing census 2000. Putrajaya: Malaysia.

Dodge, R. H., Edwards, E., \& Fullerton, S. (1996), Aberrant consumer behaviour: an investigation of consumer transgressions in the market place. Journal of Psychology and Marketing, pp. 327-355.

Donahue, M. J. (1985), Intrinsic and extrinsic religiousness: review and meta-analysis. Journal of Personality and Social Psychology, 48(2), pp. 400-419.

Feber, R. (1977), Research by convenience. Journal of Consumer Research, 1, pp. 57-58.

Ford, R. \& Richardson, W. (1994), Ethical decision making: A review of the empirical literature. Journal of Business Ethics, 13, pp. 205-221.

Galbraith, S. \& Stephenson, H. B. (1993), Decision rules used by male and female business students in making ethical judgments. Journal of Business Ethics, 12, pp. 227-233.

Gilligan, C. (1977), In a different voice: One's conception of the self and morality. Harvard Educational Review, 49, pp. 431-446.

Giorgi, L. \& Marsh, C. (1990), The Protestant work ethics is a cultural phenomenon. European Journal of Social Psychology, 20(6), pp. 499-517.

Hair, J. F., Anderson, R. E., Tatham, R. L., \& Black, W. C. (1998), Multivariate data analysis. $\left(5^{\text {th }}\right.$ ed.). Upper Saddle River, New Jersey: Prentice Hall.

Harrell, G. D. (1986), Consumer Behavior. Harcourt Brace: Javanovich.

Huffman, T. E. (1988), In the world but not of the world: Religious, alienation, and philosophy of human nature among Bible college and liberal arts college students. Dissertation. Iowa State University, Iowa: Ames.

Hunt, S. D. \& Vitell, S. J. (1993), The general theory of marketing ethics: A retrospective and revision. Ethics in Marketing, pp. 775-784.

Johnson, B. R., Jang, S. J., Larson, D. B., \& Li, S. D. (2001), Does adolescent religious commitment matter? A reexamination of the effects of religiosity on delinquency. Journal of Research in Crime and Delinquency, 38 (1), pp. 22-43.

Johnstone, R. L. (1975), Religious and society in interaction: the sociology of religion. Englewood Cliffs, NJ: Prentice Hall.

Joseph, C. (2008), Ethnicities and education in Malaysia: difference, inclusions and exclusions. Netherlands: Springer.

Keller, C. (1988), From a broken web: Separation, sexism and self. Boston: Beacon Press.

Kennedy, E. \& Lawton, L. (1998), Religiousness and business ethics. Journal of Business Ethics, 17 (2), 163-180.

Lewis, B. R. \& Bingham, G. H. (1991), The youth market for financial services. The International Journal of Bank Marketing, 9(2), pp. 3-11.

Magill, G. (1992), Theology in business ethics: Appealing to the religious imagination. Journal of Business Ethics, 11, pp. 129-135.

Mokhlis, S. (2006), The effect of religiosity on shopping orientation: An exploratory study in Malaysia. Journal of American Academy of Business, 9 (1), pp. 64-74.

Muncy, J. A. \& Vitell, S. J. (1992), Consumer ethics: An investigation of the ethical beliefs of the final consumer. Journal of Business Ethics, 24, pp. 297-311. 
Phau, I. \& Kea, G. (2007), Attitudes on university students toward business ethics: A cross-national investigation of Australia, Singapore and Hong Kong. Journal of Business Ethics, 72, pp. 61-75.

Polonsky, M. J., Brito, P. Q. \& Higgs-Kleyn, N. (2001), Consumer ethics in the European Union: A comparison of Northern and Southern views. Journal of Business Ethics, 31(11), pp. 117-130.

Rawwas, M. Y. A. (1996), Consumer ethics: An empirical investigation of the ethical beliefs of Austrian consumers. Journal of Consumer Research, 21(2), pp. 381-391.

Rawwas, M. Y. A, Strutton, D., \& Johnson, L. W. (1996), An exploratory investigation of the ethical values of American and Australian consumers. Journal of Direct Marketing, 10, pp. 52-63.

Rawwas, M. Y. A., Swaidan, Z., \& Al-Khatib, J. (2006), Does religion matter? A comparison of study of the ethical beliefs of marketing students of religious and secular universities in Japan. Journal of Business Ethics, 65, pp. 69-86.

Rawwas, M. Y. A., Vittell, S. J., \& Al-Khatib, J. (1994), Consumer ethics: The possible effects of terrorism and civil unrest on the ethical values of consumers. Journal of Business Ethics, 13, pp. 223-231.

Schuessler, K. (1971), Analyzing social data. Boston, MA: Houghton Mifflin.

Sood, J. \& Nasu, Y. (1995), Religiosity and nationality: An exploratory study of their effect on consumer behaviour in Japan and the United States. Journal of Business Research, 34 (1), pp. 1-9.

Stassens, G. (1977), A social theory model for religious social ethics. Journal of Religious Ethics, 5 (1), pp. 9-37.

Tepstra, D., Rozell, E., \& Robinson, R. (1993), The influence of religiosity and demographic variables on ethical decisions related to insider trading. Journal of Psychology, 127 (4), pp. 375-390.

The Commissioner of Law Revision (2006), Federal constitution, Putrjaya, Malaysia.

Tsalikis, J. \& Fritzsche, D. J. (1989), Business ethics: A literature review with a focus on marketing ethics. Journal of Business Ethics, 9 (9), pp. 695-743.

Vitell, S. J. (2005), Consumer ethics research: Review, synthesis and suggestions for the future. Journal of Business Ethics, 43, 33-47.

Vitell, S. J. \& Paolillo, J. G. P. (2003), Consumer ethics: The role of religiosity. Journal of Business Ethics, 46, pp. 151-162.

Vitell, S. J. \& Muncy, J. A. (2005), The Muncy-Vitell consumer ethics scale: A modification and application. Journal of Business Ethics, 62(3), pp. 267-275.

Vitell, S. J., Paolillo, J. G. P., \& Singh, J. (2005), Religiosity and consumer ethics. Journal of Business Ethics, 57, pp. 175-181.

Vitell, S. J., Paolillo, J. G. P. \& Singh, (2006), The role of money and religiosity in determining consumers' ethical beliefs. Journal of Business Ethics, 64(2), pp. 117-124.

Vitell, S. J., Singh, J., \& Paolillo, J. G. P. (2006), Consumers' ethical beliefs: the roles of money, religiosity and attitude toward business. Journal of Business Ethics, 73, pp. 369-379.

Weaver, G. R. \& Agle, B. R. (2002), Religiosity and ethical behaviour in organizations: A symbolic interactionist perspective. Academy of Management Review, 27 (1), pp. 77-98.

Worthington, E. L. Jr., Wade, N. G., Hight, T. L., McCullough, M. E., Berry, J. T., Ripley, J. S., Berry, J. W., Schmitt, M. M., Bursley, K. H., \& O'Connor, L. (2003), The religious commitment inventory-10 development, refinement and validation of a brief scale for research and counselling. Journal of Counselling Psychology, 50 (1), pp. 84-96. 